\title{
Gebelerin Hastanelerden Sağlık Hizmeti Almasını Etkileyen Faktörler Ölçeğinin Geliştirilmesi ve Psikometrik Özelliklerin İncelenmesi
}

\author{
Elif GÜRSOY*, Berrak MIZRAK ŞAHIN**, Murat BEKTAŞ***
}

\begin{abstract}
$\ddot{O} z$
Giriş: Dünya'nın birçok ülkesinde sağlık hizmetlerine erişim her zaman kolay olamamaktadır. Özellikle gelişmekte olan ülkelerde gebelerin hizmeti almasını etkileyen faktörler bulunmaktadır. Amaç: Çalışmanın amacı, gebelerin hastanelerden sağlık hizmeti almalarını etkileyen faktörlerin belirlenmesine yönelik kullanılabilecek bir ölçme aracı geliştirmektir. Yöntem: Çalışma, Ocak-Mayıs 2018 tarihleri arasında, Eskişehir ilindeki bir üniversite ve devlet hastanesinin gebe polikliniklerinde gerçekleştirilmiştir. Çalışmanın örneklemini 450 gebe oluşturmuştur. Araştırmada veri toplama aracı olarak 'Gebelik Dönemi Veri Toplama Formu' ve araştırmacılar tarafından geliştirilen 'Gebelerin Hastanelerden Sağlık Hizmeti Almasını Etkileyen Faktörler Ölçeği' kullanılmıştır. Gebelerin hastanelerden sağlık hizmeti almasını etkileyen faktörler ölçeğinin geçerlik-güvenirlik analizinde içerik geçerliliği, açıklayıcı faktör analizi, Cronbach'ın Alfa katsayısı, madde-toplam puan korelasyon yöntemleri kullanılmıştır. Bulgular: Ölçeğin kapsam geçerliği değerlendirildikten sonra test-tekrar test güvenirliği, iç tutarlılık ve yapı geçerliği incelenmiştir. Veri değerlendirmesinde; cronbach alfa analizi, madde toplam puan korelasyon yöntemleri, açıklayıcı ve doğrulayıcı faktör analizi kullanılmıştır. Ölçeğin güvenirlik ve geçerlik analizinden sonra ölçek 'hizmet kalitesi, tutum, ekonomi, ailesel/çevresel, bireysel ve mahremiyet' olmak üzere 6 alt boyut ve 37 madde ile sonuçlandırılmıştır. Ölçek alt boyutlarının her biri için ortanca değer belirlenmiştir. Bu alt boyut için ortanca değerin üzerinde bir puan elde edilmesi, alt boyutun sağlık hizmetleri alımı üzerinde olumlu bir etkiye sahip olduğunu göstermektedir. Hem açıklayıcı hem de doğrulayıcı faktör analizinde tüm faktör yüklerinin 0.30 'dan fazla olduğu bulunmuştur. Doğrulayıcı faktör analizinde tüm uyum indeksleri 0.80 'den fazla ve RMSEA değeri 0.08 'den az olarak belirlenmiştir. Ölçeğin tümünün cronbach alfa katsayısı 0.95 olarak belirlenmiştir. Sonuç: Çalışmanın sonuçları, geliştirilen ölçeğin, gebelerin hastanelerden sağlık hizmeti almalarını etkileyen faktörleri belirlemek için kullanılabilecek geçerli ve güvenilir bir ölçüm aracı olduğunu ortaya koymuştur.
\end{abstract}

Anahtar Sözcükler: Sağlık Hizmetlerine Erişim, Etkileyen Faktörler, Gebeler, Geçerlik, Güvenirlik.

\section{Abstract \\ The Development of the Affecting Factors Scale Pregnant Women Receiving Health Service from Hospital and Evaluation Psychometric Properties}

Background: Access to healthcare services is not always easy in several countries of the world, Particularly in developing countries, factors that affect the ability of pregnant women to receive healthcare services. Objectives: The aim of this study is to develop a measurement tool that can be used to determine the factors affecting pregnant women to receive health care services from hospitals. Methods: This study consisted of 450 pregnants who attended the outpatient clinic of an University and State Hospital in a city in central anatolian in Turkey between 10 December 2017 and 4 April in 2018. In data collection, the Personal Information Form and The Affecting Factors Scale Pregnant Women Receiving Health Service from Hospitals developed by the researchers were used. In the validity-reliability analysis of the The Affecting Factors Scale Pregnant Women Receiving Health Service from Hospitals scale, language and content validity, explanatory factor analysis, Cronbach's Alpha co-efficient, item-total score correlation methods were used. Results: After evaluating the content validity of the scale, test-retest reliability, internal consistency and construct validity were examined. In data evaluation; cronbach alpha analysis, item total score correlation methods, explanatory and confirmatory factor analysis were used. After the reliability and validity analysis of the scale, the scale was finalized with six sub-dimensions and 37 items. The median value for each of the scale sub-dimensions was determined. Obtaining a score above the median value for that sub-dimension indicates that the sub-dimension has a positive effect on the receipt of healthcare services. The cronbach alpha coefficient of the whole scale is 0.95 has been determined. All the factor loadings were found to be greater than 0.30 in both explanatory and confirmatory factor analysis. In confirmatory factor analysis, all of the fit indices were greater than 0.80 and RMSEA was less than 0.08. Conclusion: The results of this study revealed that the developed scale is a valid and reliable measurement tool that can be used to determine the factors that affect the receipt of healthcare services from hospitals by pregnant women.

Keywords: Access to Health Services, Affecting Factors, Pregnant Women, Reliability, Validity.

Geliş tarihi: 06.03.2020 Kabul tarihi: 01.10.2020

$\mathrm{G}$

ebelik dönemi, kadınların fizyolojik değişiklikler yaşadığı bir süreçtir. Gebelikten kaynaklanan komplikasyonlar, üreme çağındaki kadınlar arasında önemli mortalite nedenlerinden biridir. Bu nedenle bu süreçte gebelerin bilgi edinme ve bakım hizmeti alma ihtiyaçları artar. Dünya'nın birçok ülkesinde özellikle gelişmekte olan ülkelerde sağlık hizmetlerine erişim her zaman kolay olmamaktadır (1). Yapılan çalışmalar incelendiğinde dünyanın birçok ülkesinde ve ülkemizde gebelerin doğum öncesi hizmetlerden yararlanmasını engelleyen birçok faktör olduğu görülmektedir. Penchansky ve Thomas, hizmete erişimde beş ana faktörden bahsetmiştir: mevcut olanaklar (availability), ulaşılabilirlik (accessibility), kolaylık (accommodation), ödenebilir olma (affordability), kabul edilebilir olma (acceptability) (2). Özellikle gelişmekte olan ülkelerde gebelerin hizmet almasını etkileyen daha fazla faktör bulunmaktadır. Bu faktörlerin başında kadınların sosyo-demografik özellikleri, ekonomik durumu, eğitim düzeyi, kültürel inanışları ve uygulamaları, cinsiyet ayrımı, politik yapı ve çevresel koşullar gelmektedir (3). Nijerya'da gebelik, doğum ve doğum sonrası dönemde kadınların sağlık arama davranışlarını etkileyen ekonomik nedenler, bakımın kalitesi, gelenek-dini nedenler, sağlık çalışanlarının tutumu, sağlık politikaları konusunda bilgi, komplikasyon algısı ve ücretsiz bakım alabilme olmak üzere yedi faktör bulunmuştur (4). Bangladeş'te gebelik, doğum ve doğum sonrası dönemde sağ lık hizmeti arayışını etkileyen faktörleri inceleyen bir çalışma; anne yaşının,

* Eskişehir Osmangazi Üniversitesi, Sağlık Bilimleri Fakültesi, Hemşirelik Bölümü, Eskişehir, e mail: elif070@ gmail.com ORCID: 0000-0003-0147-8682 ** Eskişehir Osmangazi Üniversitesi, Sağlık Bilimleri Fakültesi, Hemşirelik Bölümü, Eskişehir, e mail: bmizrak5@ hotmail.com ORCID: 0000-0001-7757-5003 *** Dokuz Eylül Üniversitesi, Hemşirelik Fakültesi, İzmir, e mail: muratbektas35@ gmail.com ORCID: 0000-0003-3327-8204 
Araştırma

ikamet yerinin, eğitim düzeyinin, kitle iletişim araçlarına erişimin, ekonominin ve annenin çalışma durumunun gebelik, doğum ve doğum sonrası bakım sağlık hizmeti arayışı üzerinde önemli etkileri olduğunu göstermiştir (5). Hindistan'daki bir gecekondu bölgesinde gebe annelerin sağlık arama davranışı ve sağlık hizmetlerinden yararlanma durumlarını inceleyen çalışma sonuçlarına göre; gebelerin obstetrik sağlık hizmetlerinden faydalanma durumları kadınların eğitimi, gebeliği isteme durumları, ekonomik durumları, sağlık bilgisi durumları gibi toplumsal, kültürel ve ekonomik faktörlerle doğrudan ilişkili bulunmuştur (6). Kuzey Amerika'da yapılan başka bir çalışmada annelerin sağlık hizmeti almasını etkileyen faktörlerin başında ekonomik, kültürel ve coğrafi engeller geldiği saptanmıştır. Özellikle yoksulluk en önemli faktör olarak ilk sırada yer almıştır. Gelişmekte olan ülkelerdeki diğer birçok çalışma, anne sağlığı hizmetleri de dahil olmak üzere sosyo-ekonomik statü ve sağlık hizmetlerinin kullanımı arasında tutarlı ilişkiler olduğunu göstermiştir (7).

Türkiye'de bu konuda yapılmış çok fazla çalışma bulunmamaktır. Bu konuda yapılmış tek kapsamlı çalışma 2007 yılında Avrupa Komisyonu tarafından finanse edilen Sağlık Bakanlığı 'Türkiye Üreme Sağlığı Programı' (TÜSP) kapsamında yürütülen nitel bir çalışmadır. Bu çalışmada gebelerin sağlık kuruluşundan hizmet almasını etkileyen faktörler incelenmiştir (8). Özellikle kırsal bölgelerde yaşayan gebelerin ekonomik, kültürel ve toplumsal sebeplerle sağlık hizmetine ulaşmakta zorlandıkları saptanmıştır. Aynı zamanda bu nitel çalışma derinlemesine incelendiğinde engelleyici faktörler olarak karşımıza şunlar çıkmaktadır: sağlık güvencesinin olmaması ve ekonomik nedenler, sağlık kuruluşunun uzak oluşu ve ulaşım zorluğu, doğum öncesi bakım hizmetlerinin eksikliği, sağlık personelinin olumsuz davranışları, ilgisizlik ve ihmal, kayınvalide ve eşten izin alınamama, eşin uzun süre yanında olmaması, ev işlerinden ve çocuk bakımından zaman kalmaması, dil sorunu, kendini ifade edeme, utanma, doktorun erkek olması, DÖB hizmetleri sırasında önerilen ilaçların etkilerine ilişkin algılar ve resmi nikahın olmaması (8).

Aynı zamanda, Avrupa Birliğinin desteği ile 2003-2007 yılları arasında Sağlık Bakanlığı tarafından yürütülen Türkiye Üreme Sağlığı Programı sonuçlarına göre; gebeliğe bağlı ölümlerin 1/3'ü doğum öncesi dönemde gerçekleşmektedir. Bu sonuç bize Türkiye'de kadınların üçte birinin doğum öncesi bakım (DÖB) hizmetlerinden yararlanamadığını ortaya koymaktadır. 2018 Türkiye Nüfus Sağlık Araştırması (TNSA) verilerine göre gebelerin \%96'sının bir sağlık kuruluşundan bakım aldığı saptanmıştır (9). Burada söz konusu olan bakım alma kavramı, gebelerin bebeklerin cinsiyetini öğrenmek için ultrason çektirmek ya da herhangi bir şikâyetleri olduğunda doktora kontrole gitmeleridir. Bu oranın (\%96) bu açıdan incelendiğinde nicel bir değeri olmakla birlikte niteliksel açıdan düşündürücüdür.

Literatür incelendiğinde gerek diğer ülkelerde gerekse bizim ülkemizde bu tür çalışmaların ve çalışmada kullanılacak bir ölçüm aracının çok sınırlı olduğu görülmüştür. Literatürdeki bu eksikliği gidermek için çalışmada, gebelerin hastanelerden sağlık hizmeti almalarını etkileyen faktörlerin belirlenmesi amacıyla ölçek geliştirilerek, geçerlik ve güvenirliği yapılmıştır. Böyle bir ölçeğin geliştirilmesi ülkemizde gebelerin gebeliğe ilişkin hizmete erişimini engelleyen faktörleri ortaya çıkarıp bilimsel veriler 1 şı̆̆ında çalışmanın yapıldığı yer açısından hizmeti engelleyen faktörlere ilişkin hizmet sunmaya fırsat vereceği için yararlı olacağı düşünülmektedir. Ayrıca Doğum ve Kadın Sağlığı hemşireliği alanında eksik olan bu konuda bilimsel bir ölçüm aracı geliştirilmiş olup bilimsel kaynak kazandırılmış olacaktır.

\section{Araştırmanın Sorusu}

Geliştirilen Gebelerin Hastanelerden Sağlık Hizmeti Almasını Etkileyen Faktörler Ölçeği geçerli ve güvenilir bir ölçüm aracı midir?

\section{Araştırmanın Tipi}

Yöntem

Bu çalışma metodolojik tipte bir araştırmadır.

Araştırmanın Yapıldı̆̆ Y Yer ve Zaman

Çalışma, Ocak-Mayıs 2018 tarihleri arasında, Eskişehir ilindeki bir üniversite ve devlet hastanesinin gebe polikliniklerinde gerçekleştirilmiştir.

\section{Araştırmanın Evreni/Örneklemi}

Araştırmanın evrenini, Eskişehir'de yer alan bir üniversite ve devlet hastanesinin gebe polikliniklerine Ocak-Mayıs 2018 tarihleri arasında başvuran tüm gebeler oluşturmaktadır. Çalışmaya dahil edilecek örneklem sayısının belirlenmesi için, ölçek geliştirme çalışmalarında faktör analizi için örneklem sayısının 100'e kadar yetersiz, 200'e kadar orta, 300'e kadar iyi, 500' e kadar çok iyi, 1000 kişiye kadar mükemmel bir sayı olduğu rapor edilmiştir (10). Çalışmamızda 450 örnekleme ulaşılmıştır. Örneklem seçimi, çalışmanın sürdürüldüğü hastanelerden tabakalı, büyüklüğe oransal örnekleme yöntemi kullanılarak yapılmıştır. 2016 yılında Tıp Fakültesi hastanesine 6500, Eskişehir Devlet Hastanesine 13.800 gebe başvurmuştur. Tabakalı, büyüklüğe oransal seçim ile tıp fakültesi hastanesinden 144, devlet hastanesinden 306 gebe alınması gerektiği hesaplanmıştır. Çalışmaya Türkçe’yi konuşup anlayabilen, iletişim kurma problemi bulunmayan, belirtilen hastanelerin doğum ve kadın hastalıkları polikliniklerine muayene için başvuran ikinci ve üçüncü trimesterdeki primipar ve multipar gönüllü gebeler dahil edilmiştir.

\section{Ölçeğin geliştirilme süreci}

Ölçeğin geliştirilmesinde konuya ilişkin literatür incelemesi ve ülkemizde 2007 yılında Türkiye Sağlık Bakanlığı tarafından yapılan gebelerin sağlık arama davranışlarının sorgulandığı nitel çalışma etkili olmuştur. Bu çalışmada özellikle kırsal bölgelerde yaşayan gebelerin genel olarak ekonomik, kültürel ve hizmet sunumuna ilişkin faktörler nedeniyle sağlık hizmetine ulaşmakta zorlandıkları saptanmıştır (8). Literatür incelemesinde gebelerin sağlık hizmeti almalarını etkileyen faktörlere yönelik sınırlı çalışmaya rastlanmakla birlikte bu konuda geliştirilmiş bir ölçüm aracına rastlanmamıştır. Bu nedenle, bu çalışmada gebelerin hastanelerde sunulan sağlık hizmetlerinden yararlanmasını etkileyen faktörleri belirlemek amacıyla 'Gebelerin Hastanelerden Sağlık Hizmeti Almasını Etkileyen Faktörler' başlıklı bir ölçek geliştirilmiştir. 


\section{Veri Toplama Araçları}

Gebelik Dönemi Veri Toplama Formu:Araştırmacılar tarafından, araştırmacıların deneyimleri ve literatür bilgisinden $(1,8)$ yararlanılarak araştırmaya katılan gebelerin sosyo-demografik özelliklerini ve gebeliklerine ilişkin bilgilerini saptamak için hazırlanmış 14 sorudan oluşan veri toplama formudur.

Gebelerin Hastanelerden Sağllk Hizmeti Almasını Etkileyen Faktörler Ölçeği: Ölçek, gebelerin hastanelerden hizmet almasını etkileyen faktörleri belirlemek amacıyla araştırmacılar tarafından geliştirilmiştir. Ölçek için literatür taraması sonucunda ekonomik, sosyo-kültürel, bireysel, ulaşım, gebelik ve doğumla ilgili, sağlık çalışanlarına ve hastaneye bağlı etkenler gibi ana başlıklar düşünülerek 52 soruluk madde havuzu oluşturulmuştur. Kapsam geçerliliği için, geliştirilen ölçek hakkında Doğum ve Kadın Sağlığı Hemșireliği, Ölçme ve Değerlendirme alanlarında uzman 10 öğretim üyesinden görüș alınmıștır. Uzmanlardan maddeleri "madde uygun", "madde uygun ancak düzeltilmesi gerekiyor' ve "madde gereksiz" şeklinde derecelendirmeleri istenmiştir. Uzman görüşü sonrası ölçek 47 maddeye inmiş̧ir. Bu doğrultuda 47 maddelik taslak ölçeğin Kapsam Geçerlilik İndeksi (Content Validity Index = CVI) \%90 bulunmuştur. Taslak ölçek, 47 maddeden oluşmakta olup örneklem grubunda yer almayan ancak örneklemle aynı özelliği taşıyan 30 kişiye uygulanarak geri bildirim alınmıştır. Olumsuz bir geri bildiririm gelmemesi nedeniyle ana örnekleme uygulanmaya karar verilmiştir. Ölçek ana örnekleme uygulandıktan sonra ölçeğin madde toplam puan analizinden sonra korelasyon kat sayısı .20'nin altında olan üç madde ölçekten çıkarılmıştır. Yapı geçerliğini değerlendirmek için öncelikle açıklayıcı faktör analizi uygulanmışıtır. Açıklayıcı faktör analizinden sonra faktör yükü 0.30 'un altında kalan 7 madde ölçekten çıkarılmıştır (10-15). Ölçeğin güvenirlik ve geçerlik analizlerinden sonra, ölçeğe 6 alt boyut ve 37 madde ile son şekli verilmiştir. Ölçek hiç etkilemez $=1$, etkilemez $=2$, ne etkiler ne etkilemez $=3$, etkiler $=4$ ve çok etkiler $=5$ olmak üzere 5 'li likert tipinde bir ölçektir. Ölçekte gebelerin hastaneden hizmet almasını olumsuz etkileyen maddeler ters çevrilerek puanlanmaktadır. Buna göre 3, 5, 6, 7, 16, 17, 21, 24, 25, 36, 37, 39, 40, 43, 44 numaralı maddeler ters çevrilerek puanlanmaktadır. Ölçek alt boyutlarının her biri için ortanca değer belirlenmiştir. Alt boyutlar için belirlenen ortanca değerin üzerinde puan alınması, sağlık hizmeti almada o alt boyutun olumlu etkisinin olduğunu göstermektedir. Alt boyutlardan 'Hizmet Kalitesi' alt boyutu 7 maddeden oluşmakta ve bu alt boyuttan 7-35 arasinda puan alınmaktadır. Ortanca değer 21'dir. 'Tutum' alt boyutu 9 maddeden oluşmakta ve 9-45 arasında puan alınmaktadır. Ortanca değer 27'dir. 'Ekonomi' alt boyutu üç maddeden oluşmakta ve 3-15 puan arasında puan alınmaktadır. Ortanca değer 9'dur. Ailesel/çevresel' alt boyutu altı maddeden oluşmaktadır ve en düşük 6 , en yüksek 30 puan alınmaktadır. Ortanca değer 18'dir. 'Bireysel' alt boyutu 8 maddeden oluşmakta, 8-40 arasında puan alınmaktadır. Ortanca değer 24'tür. 'Mahremiyet' alt boyutu ise 4 maddeden oluşmakta, 4-20 arasında puan alınmaktadır. Ortanca değer 12'dir. Ölçekten toplam puan alınmamaktadır, alt boyut puanlarına göre değerlendirilmektedir.

\section{Verilerin Toplanmast}

Veri toplama yüz yüze görüşme yöntemi ile yapılmıştır. Veri toplama her katılımcı için 15-20 dakika sürmüştür.

\section{Verilerin Değerlendirilmesi}

Verilerin analizinde tanımlayıcı istatistikler için yüzdelik ve ortalama, verilerin normal dağılıma uyup uymadığı Shapiro-Wilk normallık testi, uzman görüşlerinin uyumluluk analizi için kapsam geçerlik indeksi, ölçek ve alt boyutların madde toplam puan analizi için Pearson korelasyon analizi, ölçek ve alt boyutların iç tutarlılığını belirlemek için Cronbach Alfa katsayısı, iki yarıya bölme analizi, madde-faktör ilişkisinin belirlenmesi için açıklayıcı faktör analizi, maddelerin ve alt boyutların ölçeğin özgün yapısını açıklayıp açıklamadığı doğrulayıcı faktör analizi, ölçeğin toplanabilir özelliği olup olmadığını değerlendirmede Tukey toplanabilirlik analizi, ölçeğin tepki yanlılı̆̆ını belirlemede Hotelling $\mathrm{T}$ kare testi kullanılmıştır. Veri değerlendirilmesinde hata (yanılma) payı $\mathrm{p}=.05$ olarak alınmıştır.

\section{Araștırmanın Etik Yönü}

Eskişehir Osmangazi Üniversitesi Girişimsel Olmayan Klinik Araştırmalar Etik Kurulu'ndan 29.09.2017 tarihli ve 80558721/G-279 onay numarası ile etik kurul izni ve araştırmanın yapıldığı hastanelerden kurum izni alınmıştır. Çalışmaya katılmayı kabul eden gebelerden sözel ve bilgilendirilmiş yazılı onam alındı. Makalenin tüm aşamalarında araştırma ve yayın etiğine uyulmuş̧ur.

\section{Gebelerin Sosyo-Demografik Özellikleri}

\section{Bulgular}

Çalışmadaki gebelerin yaş ortalaması $28.37 \pm 5.32^{`}$ dir (min-max:18-42). Katılımcıların 163’ü (\%36.2) lisans mezunu, 321’i (\%71.3) herhangi bir işte çalışmamaktadır. Gebelerin 219’u (\%48.7) primipar, gebelik haftası ortalamaları 25.36 8.63 'tür. Gebelerden 394'ü (\%87.6) düzenli olarak gebelik kontrollerine gittiğini belirtirken, 56’s1 (\%12.4) düzenli olarak gebelik kontrollerine gidemediğini bildirmiş̧tir.

\section{Ölçeğin Geçerlik Analizleri}

Kaiser-Meyer Olkin (KMO) kat sayıs1 0.90, Bartlett testi X2 değeri 7520.33 ve p $=.000$ olarak saptanmıştır. Ölçeğin birinci alt boyutu toplam varyansın \%27.98'ini, ikinci alt boyutu toplam varyansın \%8.91'ini, üçüncü alt boyut toplam varyansın $\% 5.41$ 'ini, dördüncü alt boyut toplam varyansın $\% 4.18$ 'ini, beşinci alt boyut toplam varyansın $\% 3.93$ 'ünü ve altıncı alt boyut toplam varyansın \%3.48'ini açıklamaktadır. Altı alt boyut toplam varyansın \%53.89'ünü açıklamaktadır. Ölçeğin birinci alt boyutunun faktor yükleri 0.37-0.66 arasında değiştiği, ikinci alt boyutun faktör yüklerinin 0.55-0.69 arasında değiştiği, üçüncü alt boyutun faktör yüklerinin 0.40-0.55 arasında, dördüncü alt boyutun faktör yüklerinin 0.28-0.52 arasında, beşinci alt boyutun faktör yüklerinin 0.33-0.56 arasında ve altıncı alt boyutun faktör yüklerinin 0.33-0.44 arasında değiştiği belirlenmiştir (Tablo $1)$. 
Tablo 1. Açıklayıcı Faktör Analiz Sonuçları $(n=450)$

\begin{tabular}{|c|c|c|c|c|c|c|}
\hline \multirow[b]{2}{*}{ Items } & \multicolumn{6}{|c|}{ Alt Boyut Faktör Yükleri } \\
\hline & $\begin{array}{c}\text { Hizmet } \\
\text { Kalitesi }\end{array}$ & Tutum & Ekonomik & Ailesel/çevresel & Bireysel & Mahremiyet \\
\hline M5 & 0.400 & & & & & \\
\hline M7 & 0.372 & & & & & \\
\hline M12 & 0.616 & & & & & \\
\hline M15 & 0.660 & & & & & \\
\hline M33 & 0.653 & & & & & \\
\hline M38 & 0.641 & & & & & \\
\hline M41 & 0.647 & & & & & \\
\hline M9 & & 0.559 & & & & \\
\hline M10 & & 0.566 & & & & \\
\hline M16 & & 0.694 & & & & \\
\hline M17 & & 0.670 & & & & \\
\hline M20 & & 0.586 & & & & \\
\hline M23 & & 0.632 & & & & \\
\hline M26 & & 0.670 & & & & \\
\hline M35 & & 0.668 & & & & \\
\hline M42 & & 0.631 & & & & \\
\hline M28 & & & 0.556 & & & \\
\hline M37 & & & 0.402 & & & \\
\hline M43 & & & 0.423 & & & \\
\hline M21 & & & & 0.281 & & \\
\hline M24 & & & & 0.527 & & \\
\hline M25 & & & & 0.442 & & \\
\hline M27 & & & & 0.519 & & \\
\hline M34 & & & & 0.444 & & \\
\hline M44 & & & & 0.402 & & \\
\hline M13 & & & & & 0.629 & \\
\hline M14 & & & & & 0.606 & \\
\hline M30 & & & & & 0.576 & \\
\hline M31 & & & & & 0.529 & \\
\hline M32 & & & & & 0.625 & \\
\hline M36 & & & & & 0.331 & \\
\hline M39 & & & & & 0.376 & \\
\hline M40 & & & & & 0.347 & \\
\hline M3 & & & & & & 0.331 \\
\hline M6 & & & & & & 0.360 \\
\hline M18 & & & & & & 0.447 \\
\hline M19 & & & & & & 0.442 \\
\hline $\begin{array}{l}\text { Açıklanan } \\
\text { Varyans } \\
(\%)\end{array}$ & 27.98 & 8.91 & 5.41 & 4.18 & 3.93 & 3.48 \\
\hline Açıklanan & 53.89 & & & & & \\
\hline Toplam & & & & & & \\
\hline $\begin{array}{l}\text { Varyans } \\
(\%)\end{array}$ & & & & & & \\
\hline Özdeğer & 10.352 & 3.299 & 2.004 & 1.550 & 1.456 & 1.290 \\
\hline
\end{tabular}

Altı faktörlü modelin hesaplanan ki-kare değeri 2299.89, serbestlik derecesi 603 ve $\mathrm{p}=.000$ olarak saptanmıştır. X2/SD bölümü ise 3.81 olarak belirlenmiştir. Uyum indekslerinden Root Mean Square Error of Approximation (RMSEA) 0.079, Goodness-of-fit Index (GFI) 0.80, Comperative Fit Index (CFI) 0.94, Incremental Fit Index (IFI) 0.94, Relative Fit Index (RFI) 0.94, Normed Fit Index (NFI) 0.92 ve Turker-Lewis Index (TLI) 0.94 olarak saptanmıştır (Tablo 2). 
Tablo 2. Model Uyum Indeksleri

\begin{tabular}{lllllllllll}
\hline & $X^{2}$ & SD & $X^{2} /$ SD & RMSEA & GFI & CFI & IFI & RFI & NFI & TLI \\
\cline { 2 - 9 } \\
$\begin{array}{l}\text { Faktörlü } \\
\text { Model }\end{array}$ & 2299.89 & 603 & 3.814 & 0.079 & 0.80 & 0.94 & 0.94 & 0.91 & 0.92 & 0.94 \\
\hline
\end{tabular}

Doğrulayıcı Faktör Analizi (DFA) sonucunda ölçeğin birinci alt boyutunun faktör yükleri 0.27-0.70 arasında değiştiği, ikinci alt boyutun faktör yüklerinin 0.50-0.72 arasında değiştiği, üçüncü alt boyutun faktör yüklerinin 0.50-0.61 arasında, dördüncü alt boyutun faktör yüklerinin 0.31-0.64 arasında, beşinci alt boyutun faktör yüklerinin 0.31-0.61 arasında ve altınc1 alt boyutun faktör yüklerinin 0.36-0.82 arasında değiştiği belirlenmiştir (Şekil 1). 


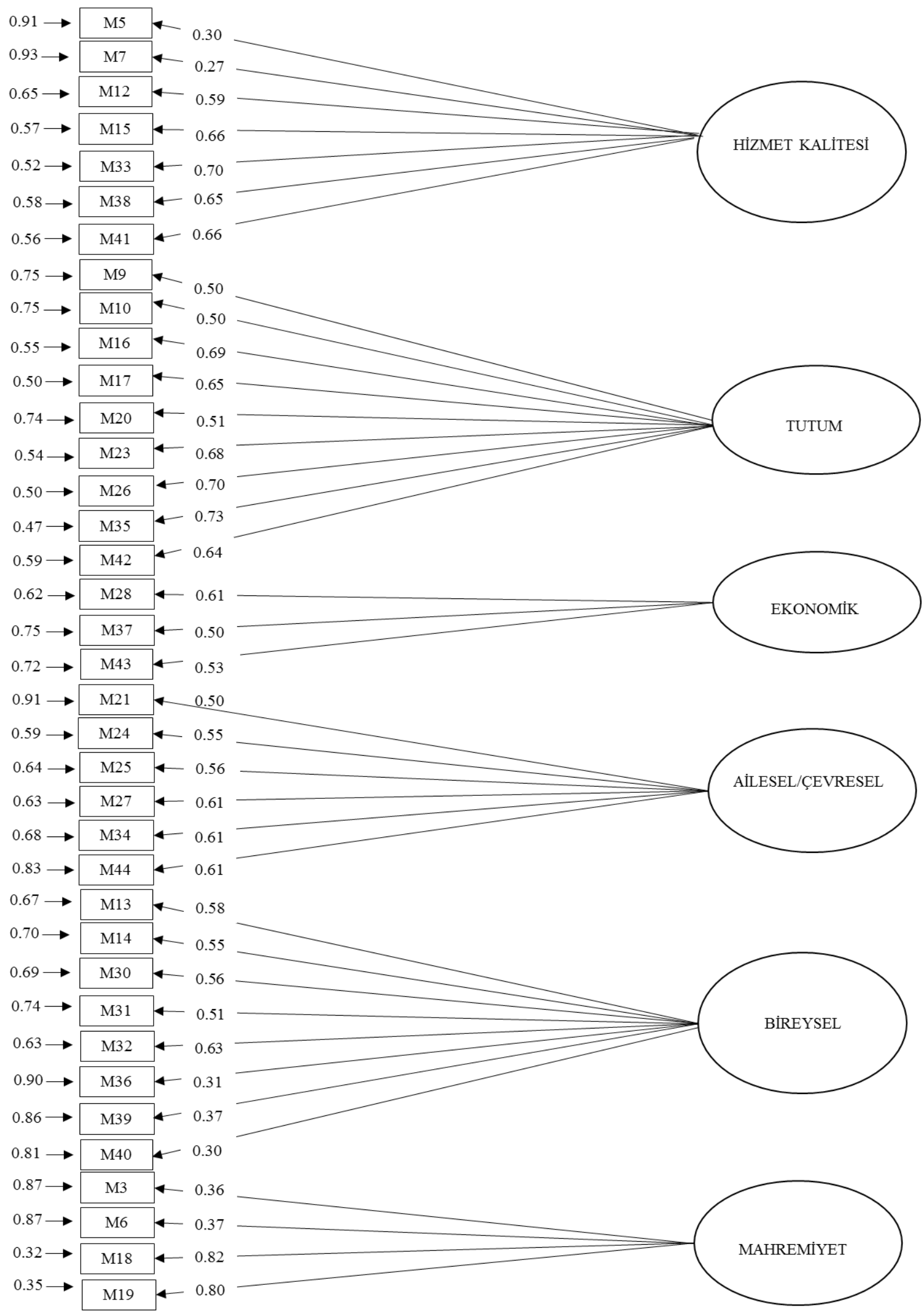

\section{Şekil 1. Doğrulayıcı Faktör Analizi}




\section{Ölçeğin Güvenirlik Analizleri}

Ölçeğin tamamının cronbach alfa katsayısı .95 olarak belirlenmiş̧tir. Alt boyutlarının alfa değeri sırasıyla $.75, .85, .60, .69$ ve .66 olarak saptanmıştır. İki yarıya bölme analizi sonucunda birinci yarının cronbach alfa değeri .86, ikinci yarının cronbach alfa değeri .87, spearmen Brown kat sayıs1 .82, Guttman-split-half kat sayıs1 .82, iki yarı arasındaki korelasyon kat sayısı ise .69 olarak saptanmıştır. Ölçeğin tamamı için taban etki ve tavan etki olmadığı saptanmıştır. Birinci alt boyut için taban etki $\% 2.7$ ve tavan etki $\% 0.2$, ikinci alt boyut için taban etki $\% 5.8$ ve tavan etki $\% 0.4$, üçüncü alt boyut için taban etki $\% 6.7$ ve tavan etki \% 1.8 , dördüncü alt boyut için taban etki $\% 0.7$ ve tavan etki $\% 0.9$, beşinci alt boyut için taban etki $\% 1.3$ ve tavan etki $\% 0.2$ ve altıncı alt boyut için taban etki \%1.1 ve tavan etki \%2.7 olarak saptanmışıtır (Tablo 3).

Tablo 3. Ölçek ve Alt Boyutların Güvenirlik Analiz Sonuçları (n=450)

\begin{tabular}{|c|c|c|c|c|c|c|c|c|c|}
\hline Alt boyutlar & $\begin{array}{c}\text { Cronbach } \\
\alpha\end{array}$ & $\begin{array}{c}\text { Birinci } \\
\text { yar1 } \\
\text { Cronbach } \\
\alpha\end{array}$ & $\begin{array}{c}\text { İkinci yarı } \\
\text { Cronbach } \\
\alpha\end{array}$ & $\begin{array}{l}\text { Spearman- } \\
\text { Brown }\end{array}$ & $\begin{array}{l}\text { Guttman } \\
\text { split-half }\end{array}$ & $\begin{array}{l}\text { İki yarı } \\
\text { arasında } \\
\text { korelasyon }\end{array}$ & $\mathrm{M} \pm \mathrm{SD}$ & $\begin{array}{c}\text { Taban } \\
\text { Etki } \\
\%\end{array}$ & $\begin{array}{c}\text { Tavan } \\
\text { Etki } \\
\%\end{array}$ \\
\hline Ölçek Toplam & .921 & .869 & .873 & 822 & .821 & .698 & $93.95 \pm 24.56$ & 0.0 & 0.0 \\
\hline Hizmet & .751 & & & & & & $15.79 \pm 5.36$ & 2.7 & 0.2 \\
\hline Tutum & .859 & & & & & & $18.78 \pm 7.39$ & 5.8 & 0.4 \\
\hline Ekonomik & .606 & & & & & & $7.91 \pm 2.96$ & 6.7 & 1.8 \\
\hline Ailesel/çevresel & .694 & & & & & & $17.59 \pm 4.99$ & 0.7 & 0.9 \\
\hline Bireysel & .715 & & & & & & $20.58 \pm 6.03$ & 1.3 & 0.2 \\
\hline Mahremiyet & .660 & & & & & & $11.44 \pm 3.63$ & 1.1 & 2.7 \\
\hline
\end{tabular}

Ölçek maddelerinin ölçek toplam puanla korelasyonlarının .25-.64 arasında, birinci alt boyut maddeleri ile alt boyut toplam puanı ile korelasyonunun .51-.70 arasında, ikinci alt boyut maddeleri ile alt boyut toplam puanı arasındaki korelasyonun .58-.77 arasında, üçüncü alt boyut maddeleri ile alt boyut toplam puanı arasındaki korelasyonun .64-.79 arasında, dördüncü alt boyut maddeleri ile alt boyut toplam puanı arasındaki korelasyonun .53-.70 arasında, beşinci alt boyut maddeleri ile alt boyut toplam puanı arasındaki korelasyonun .51-.65 arasında ve altıncı alt boyut maddeleri ile alt boyut toplam puanı arasındaki korelasyonun .60-.81 arasında değiştiği saptanmıştır (Tablo 4). 


\begin{tabular}{|c|c|c|c|}
\hline Alt ölçekler & Maddeler & $\begin{array}{c}\text { Madde-Toplam } \\
\text { Puan Korelasyonu } \\
(\boldsymbol{r})^{*}\end{array}$ & $\begin{array}{l}\text { Madde- Alt Ölçek Toplam } \\
\text { Puan korelasyonu } \\
(r)^{*}\end{array}$ \\
\hline \multirow[t]{7}{*}{ Hizmet } & M5 & .439 & .564 \\
\hline & M7 & .421 & .513 \\
\hline & M12 & .583 & .697 \\
\hline & M15 & .610 & .705 \\
\hline & M33 & .599 & .663 \\
\hline & M38 & 609 & .670 \\
\hline & M41 & .606 & .651 \\
\hline \multirow[t]{9}{*}{ Tutum } & M9 & .547 & .664 \\
\hline & M10 & .554 & .671 \\
\hline & M16 & .647 & .779 \\
\hline & M17 & .626 & .760 \\
\hline & M20 & .597 & .586 \\
\hline & M23 & .573 & .678 \\
\hline & M26 & .619 & .712 \\
\hline & M35 & .623 & .702 \\
\hline & M42 & .587 & .641 \\
\hline \multirow[t]{3}{*}{ Ekonomik } & M28 & .545 & .649 \\
\hline & M37 & .462 & .792 \\
\hline & M43 & .473 & .795 \\
\hline \multirow[t]{6}{*}{ Ailesel } & M21 & .253 & .536 \\
\hline & M24 & .549 & .706 \\
\hline & M25 & .472 & .699 \\
\hline & M27 & .517 & .623 \\
\hline & M34 & .467 & .639 \\
\hline & M44 & .449 & .566 \\
\hline \multirow[t]{8}{*}{ Bireysel } & M13 & .608 & .642 \\
\hline & M14 & .572 & .620 \\
\hline & M30 & .534 & .495 \\
\hline & M31 & .539 & .614 \\
\hline & M32 & .602 & .651 \\
\hline & M36 & .396 & .544 \\
\hline & M39 & .436 & .554 \\
\hline & M40 & .418 & .511 \\
\hline \multirow[t]{4}{*}{ Mahremiyet } & M3 & .375 & .601 \\
\hline & M6 & .259 & .602 \\
\hline & M18 & .495 & .791 \\
\hline & M19 & .408 & .814 \\
\hline
\end{tabular}

$* p<.001$

\section{Tartışma}

Çalışmada uzman görüşü sonucu kapsam geçerlik indeksi 0.80 'in altında olan beş madde ölçekten çıkarılmıştır. Verilerin faktör analizi için yeterli ve uygun olup olmadığı Kaiser-Meyer-Olkin kat sayısı (KMO) ve Bartlett's testi ile değerlendirilmiştir. Bartlett's testinin anlamlı ve KMO değerinin 0.60 'tan büyük olması verilerin faktör analizi yapmaya uygun ve örneklem sayısının yeterli olduğunu göstermektedir. Çalışmamızda, KMO değeri 0.60'tan büyük, aynı zamanda Bartlett's test sonucu anlamlı bulunmuştur. Bulgularımız verilerin faktör analizi yapmaya uygun olduğunu göstermiştir. Bu çalışmadaki açıklayıcı faktör analizi sonucunda ölçeğin altı alt boyuttan oluştuğu, altı alt boyutun toplam varyansın \%53.89'unu açıkladı̆̆ belirlenmiştir. Bu çalışmada yapılan açıklayıcı faktör analizi sonucunda dördüncü alt boyuttaki 21. madde dişında diğger alt boyuttaki tüm maddelerin faktör yüklerinin 0.30 'un üzerinde olduğu belirlenmiştir. Literatürde çok boyutlu ölçeklerde açıklanan toplam varyansın \%40'tan ve faktör yüklerinin 0.30'dan büyük olmasının yeterli olduğu belirtilmektedir. Bu çalışmada açıklanan toplam varyansın \%50'nin üstünde ve bir madde dışında tüm faktör yüklerinin 0.30 'dan büyük olması ölçeğin güçlü bir yapı geçerliliğine sahip olduğunu göstermiştir (10-15).

Literatürde doğrulayıcı faktör analizi model uyum göstergelerinin $>0.85, \mathrm{X} 2 / \mathrm{DF}$ bölümünün beşten küçük ve RMSEA'nın $<0.08$ olması iyi uyum göstergesi olarak kabul edilmektedir (10-15). Bu çalışmadaki DFA sonucunda model uyum göstergelerinin 0.85 'den büyük, $\mathrm{X}^{2} / \mathrm{df}$ oranının beşten (5) küçük ve RMSEA 0.08'den küçük olduğu saptanmıştır (Şekil 1). DFA sonucunda bir madde dişında tüm alt boyutlardaki faktör yüklerinin 0.30 'dan büyük, uyum indekslerinin 0.85 'in üstünde ve RMSEA'nın 0.08'in altında olduğu belirlenmiştir. Bu çalışmadaki DFA sonuçları, verilerin modelle uyumlu 
Araştırma

olduğunu, üç faktörlü yapıyı doğruladığını, alt boyutların ölçekle ilişkili olduğunu, her alt boyuttaki maddelerin kendi faktörünü yeterli olarak tanımladığını göstermiştir.

Açıklayıcı ve doğrulayıcı faktör analizi sonucunda sadece iki maddenin faktör yükü 0.30'un altında kalmıştır. Faktör yükü düşük olan maddelerin ölçekten çıkartılmadan önce madde-ölçek toplam puan ve madde-alt ölçek toplam puan korelasyonlarına bakılması önerilmektedir. Korelasyon değerleri .25'in üstündeyse ve doğrulayıcı faktör analizinde de yapıyı bozmuyorsa maddelerin ölçekte kalabileceği belirtilmektedir (10-15). Çalışmamızda iki maddenin madde-toplam ve madde alt boyut toplam puan korelasyonlarının $.25^{\prime}$ in üstünde olduğu, DFA'da yapıyı bozmadığı ve teorik olarak ölçülmesi gereken maddeler olması nedeniyle maddelerin ölçekte bırakılmasına karar verilmiştir. Çalışmadaki açıklayıcı ve doğrulayıcı faktör analizi sonuçları, ölçeğin yapı geçerliliğini destekleyerek, ölçeğin geçerli bir araç olduğunu ortaya koymaktadır.

\section{Güvenirlik Analizleri}

Cronbach alfa katsayısı, maddelerin ölçülmek istenen konuyla ilgili olup olmadığını ve aynı konuyu ölçüp ölçmediğini gösterir. Ölçeklerde bu değerin .60 ile .80 arasında olması ölçeğin oldukça güvenilir ve .80 ile 1.00 arasında olmasının ise ölçeğin yüksek düzeyde güvenilir olduğunu göstermektedir (10-15). Bu çalışmada ölçeğin tümü için alfa değerinin .95 ve alt boyutların alfa değerinin .60'ın üstünde olduğu saptanmıştır. Çalışmada ölçeğin bütünü için yüksek düzeyde güvenirliğe ulaşılırken, alt boyutlarda ise ölçeğin oldukça güvenilir olduğu belirlenmiştir. Çalışmadan elde edilen bulgular maddelerin istenilen konuyu yeterli düzeyde ölçtüğünü, maddelerin alt boyutlarla yeterli düzeyde ilişkili olduğunu, ölçeğin ve alt boyutların oldukça iyi düzeyde güvenirliğe sahip olduğunu göstermiştir.

Güvenirliğin değerlendirilmesinde ayrıca iki yarıya bölme yöntemi kullanılmıştır. İki yarıya bölme analizinde her iki bölümün cronbach alfa değerlerinin .70'in üstünde olması, iki yarı arasında güçlü ve anlamlı bir ilişki olması, hem SpearmanBrown hem de Guttman Split-Half katsayılarının 0.80'in üstünde olması istenmektedir (10-15). Çalışmamızda iki yarıya bölme analizi sonucunda her iki yarının cronbach alfa değerinin ve Spearman-Brown ile Guttman Split-Half katsayılarının da .80'in üstünde olduğu saptanmıştır. Bu sonuçlar ölçeğin yüksek düzeyde güvenirliğe sahip olduğunu, maddelerin birbiri ile ilişkili ve ölçülmek istenen yapıyı yeterli düzeyde temsil ettiğini göstermiştir.

Özellikle literatürde ölçeklerin güvenirlik ve geçerliliğini değerlendirmede taban ve tavan etkinin de kullanılmasını önerilmektedir. Tavan ve taban etkinin \%20'nin altında olması gerekmektedir. Bu çalışmada ölçeğin toplam puan ve alt ölçek toplam puan taban ve tavan etki değerleri \%20'nin altında olduğu saptanmıștır (10-15). Taban ve tavan etki değerlerinin \%20'nin altında olması ölçeğin güvenilir bir ölçüm aracı olduğu ve ölçülmek istenen yapıyı yeterli düzeyde ölçtüğünü göstermiştir.

Maddelerin ölçek ve alt boyutlarla ilişkisini, maddelerin ölçeğin ölçmek istediği yapıyı ne düzeyde ölçtüğünü belirlemede madde- ölçek toplam puan ve madde-alt ölçek toplam puan korelasyonlarının kullanılması önerilmektedir. Literatürde korelasyon değerinin .20'nin üstünde olması maddenin yapıyı yeterli düzeyde ölçtüğünü gösterdiği vurgulanmaktadır (10-15). Bu çalışmada maddelerin hem toplam puanla hem de alt ölçek toplam puanla korelasyonlarının .20’nin üstünde olduğu saptanmıştır. Bu sonuç maddelerin ölçmek istenen niteliği yeterli düzeyde ölçtüğü ve ölçeğin yüksek düzeyde güvenirliğe sahip olduğunu göstermiştir.

\section{Kisitlılıklar}

Bu çalışmada gelişigüzel örneklemin kullanılmış olması yani sadece ölçeği doldurmayı kabul eden kişilerin ölçeği doldurmuş olması bu çalışmanın sınırlılığıdır. Çalışmanın diğer bir sınırlılığı ise kompozit güvenirliğinin hesaplanamamış olmasıdır. Son sınırlılığ 1 ise alınan örneklemin ve değerlendirilen sağlık hizmetinin Türkiye'nin sadece bir bölgesini içermesidir.

\section{Sonuçların Uygulamada Kullanımı}

$\mathrm{Bu}$ çalışmada geliştirilen ölçeğin, gebelerin hastanelerden sağlık hizmeti almalarını etkileyen faktörleri belirlemede kullanılabilecek geçerli ve güvenilir bir ölçüm aracı olduğu belirlenmiştir. Kadın sağlığı hemşireleri ve ebeler bu ölçeği gebelerin sağlık hizmetlerinin alınmasını etkileyen faktörleri belirlemek, engelleri ve kolaylaştırıcı faktörleri ortaya koymak için kullanabilirler. Böylece bilimsel veriler 1şı̆̆ında gebelerin hizmet alımını etkileyen olumsuz faktörlerin önlenmesi, kolaylaştırıcı faktörlerin desteklenmesi sağlık hizmetlerinden yararlanmanın kolaylaştırılması ve hizmet kalitesin arttırılması açısından uygulamaya katkı sağlayacağı düşünülmektedir. Geliştirilen ölçek kullanılarak gebelerin sosyo-demografik özellikler gibi bağımsız değişkenlerle ilişkisi belirlenebilir.

\section{Bilgilendirme}

Yazarların katkı oranı beyanı şöyledir: fikir/kavram EG, BMŞ; tasarım EG, BMŞ, MB; denetleme/danışmanlık EG, BMŞ, MB; veri toplama ve işleme EG, BMŞ; analiz ve yorum MB; kaynak taraması EG, BMŞ, MB; makalenin yazımı EG, BMŞ, MB; eleştirel düşünme EG, BMŞ, MB; araştırmanın bütçesi EG, BMŞ, MB.

Araştırma ile ilgili herhangi bir projeden ya da firmadan destek alınmamıştır. Araştırmanın bütçesi araştırmacılar tarafından karşılanmıştır.

Eskişehir Osmangazi Üniversitesi Girişimsel Olmayan Klinik Araştırmalar Etik Kurulu'ndan 29.09.2017 tarihli ve 80558721/G-279 onay numarası ile izin alınmıştır.

\section{Kaynaklar}

1. Ojewole F, Oludipe Y. Pregnancy-related information need and information-seeking pattern among pregnant women attending antenatal clinic at Ikorodu General Hospital, Lagos state, Nigeria. Euro Sci J. 2017;13:436-447.

2. Penchansky R, Thomas JW. The concept of access: definition and relationship to consumer satisfaction. Medical Care. 1981:127-40.

3. Shaikh BT, Hatcher J. Health seeking behaviour and health service utilization in Pakistan: challenging the policy makers. J Public Health Res. 2004;27(1):49-54. 
Araştırma

4. Edu BC, Agan TU, Monjok E, Makowiecka K. Effect of free maternal health care program on health-seeking behaviour of women during pregnancy, intra-partum and postpartum periods in cross river state of nigeria: a mixed method study. Open Access Maced J Med Sci. 2017;5(3):370.

5. Islam MM, Masud MS. Health care seeking behaviour during pregnancy, delivery and the postnatal period in bangladesh: assessing the compliance with WHO recommendations. Midwifery. 2018;63:8-16.

6. Kotecha P, Patel S, Shah S, Katara P, Madan G. Health seeking behavior and utilization of health services by pregnant mothers in Vadodara slums. Healthline. 2012;3(1):30-2.

7. Chomat AM, Solomons NW, Montenegro G, Crowley C, Bermudez OI. Maternal health and health-seeking behaviors among indigenous Mam mothers from Quetzaltenango, Guatemala. Rev Panam Salud Publica. 2014;35:113-20.

8. Sağlık Bakanlığı. Sağlık arama davranışı araştırması ana raporu. Ana Çocuk Sağlığı ve Aile Planlaması Genel Müdürlüğü; 2007. p. 30-55.

9. Hacettepe Üniversitesi Nüfus Etütleri Enstitüsü. Türkiye nüfus ve sağlık araştırması (TNSA). Ankara, 2018.

10. DeVellis RF. Scale development: theory and applications (applied social research methods). Social Research. 2003;900:14929.

11. Polit DF, Beck CT, Owen SV. Is the CVI an acceptable indicator of content validity? Appraisal and recommendations. Res Nurs Health. 2007;30(4):459-67.

12. Rattray J, Jones MC. Essential elements of questionnaire design and development. J Clin Nurs. 2007;16(2):234-43.

13. Şencan H. Sosyal ve davranışsal ölçümlerde güvenilirlik ve geçerlilik (reliability and validity in social and behavioral measurement). İçinde Şencan H, Güvenirlik Katsayısı ve Güvenirlik İndeksi. Ankara Seçkin Yayınevi; 2005:165.

14. Simsek ÖF. Yapısal eşitlik modellemesine giriş - temel ilkeler ve LISREL uygulamaları. İçinde Simsek ÖF, Temel Kavramlar ve Uygulama Alanları. Ankara Ekinoks Yayınlar1; 2007:41-66.

15. Terwee CB, Bot SD, de Boer MR, van der Windt DA, Knol DL, Dekker J, et al. Quality criteria were proposed for measurement properties of health status questionnaires. J Clin Epidemiol. 2007;60(1):34-42. 